\title{
Dry ice-trap collection of mosquitoes flying near a tree canopy in Nagasaki, Japan, with special reference to Aedes albopictus (Skuse) and Culex pipiens pallens Coquillett (Diptera: Culicidae)
}

\author{
Yoshio Tsuda ${ }^{1)}$, Yoshihide Maekawa ${ }^{2)}$, Susumu Saita ${ }^{2)}$, \\ Maiko HasegaWA ${ }^{2)}$ and Masahiro TAKAGI ${ }^{2)}$ \\ 1) Department of Medical Entomology, National Institute of Infectious Diseases, \\ 1-23-1 Toyama, Shinjuku, Tokyo, 162-8640 Japan \\ 2) Department of Vector Ecology \& Environment, Institute of Tropical Medicine, \\ Nagasaki University, Sakamoto 1-12-4, Nagasaki, 852-8523 Japan
}

(Received: 22 May 2003; Accepted: 1 August 2003)

\begin{abstract}
Flying mosquitoes were collected at a pair of collection sites at different heights from the ground by a suction trap enhanced with $1 \mathrm{~kg}$ of dry ice in summer in 2001 and 2002, on the campus of Nagasaki University, School of Medicine, and on a small desert island in Nagasaki, Japan. One collection site was near a tree canopy (6-12 $\mathrm{m}$ above the ground) and the other one at about $1 \mathrm{~m}$ above the ground. At each collection site, the trap was operated for $24 \mathrm{~h}$ to collect both nocturnal and diurnal species. The following 9 species were encountered; Aedes albopictus (Skuse), Ochlerotatus nipponicus LaCasse et Yamaguti, Culex pipiens pallens Coquillett, Armigeres subalbatus (Coquillett), $C x$. tritaeniorhynchus Giles, $C x$. halifaxi Theobald, $C x$. bitaeniorhynchus Giles, Orthopodomyia anopheloides (Giles), Tripteroides bambusa (Yamada). The proportion of mosquitoes collected near the tree canopy was calculated for 4 dominant species; 3.9 (females) and 1.2\% (males) for Ae albopictus, $64.5 \%$ for females of $C x$. pipiens pallens, $19 \%$ for females of $A r$. subalbatus and $26.7 \%$ for females of $C x$. tritaeniorhynchus. The vertical distribution of flying mosquitoes in relation to the location of their vertebrate host is discussed.
\end{abstract}

Key words: vertical distribution, mosquitoes, Aedes albopictus, Culex pipiens pallens, dry ice trap

\section{INTRODUCTION}

Vertical distributions of flying mosquitoes have been examined mainly in West Africa (Snow, 1975, 1979, 1982; Gilles and Wilkes, 1976; Haddow et al., 1961; Corbet, 1961a,b; Snow and Wilkes, 1977; Gillies, 1988; Clements, 1999), and no information is available for Japanese mosquitoes. In some field studies, ornithophagous mosquitoes, such as Culex weshei in West Africa and $C x$. pipiens and Culiseta morsitans in England, were caught at higher elevations than near the ground (Snow, 1975, 1982;
Gillies and Wilkes, 1976; Service, 1971) suggesting the overlap of vertical distribution of feeding mosquitoes with that of their vertebrate host (Clements, 1999). Clarification of the place of feeding and the blood source of mosquitoes is essential to understand the transmission dynamics of mosquito-borne diseases, which include wild animals as well as humans in the transmission cycle, like West Nile Virus in USA (Bernard et al., 2000; Kulasekera et al., 2000).

Aedes albopictus (Skuse) is a dominant mosquito in Nagasaki city, Japan (Iriarte et al., 1991; Tsuda et al., 1994), and shows 
a wide range of host animals including man and birds, although the feeding pattern largely depends on the availability of the host animals (Hawley, 1988). Sakakibara (1980) observed egg-laying activities of Ae. albopictus in Mie, Japan by using ovi-traps hung at different heights from the ground, and found that about 60 and $5 \%$ of eggs were laid in the ovi-trap on the ground and the highest position $16 \mathrm{~m}$ above the ground), respectively. Culexpipiens pallens Coquillett is the most common mosquito in human dwelling areas in Japan and is primarily an avian feeders, while they feed severely also on man and other mammals (Tanaka et al., 1979). Because of the clear difference in bloodfeeding periodicity, host-seeking behavior and host preference between the two species, a different vertical distribution of flying mosquitoes is expected between them.

By using a dry ice trap, the present study was conducted to compare the vertical distribution of flying mosquitoes between Ae. albopictus and Cx. pipiens pallens in two study areas, an urban area and a small desert island where availability of host animals was different.

\section{Materials and Methods}

\section{Study area}

Two areas were selected for this study; one was located at the northern edge of a small woods on the campus of Nagasaki University, School of Medicine, Nagasaki, Japan, and the other one was on a small desert island, Maejima, which was located about $40 \mathrm{~km}$ east of Nagasaki city, Japan $\left(32^{\circ} 45^{\prime} 34.2^{\prime \prime} \mathrm{N}, \quad 130^{\circ} 02^{\prime} 26.7^{\prime \prime} \mathrm{E}\right)$. The study area on the campus of Nagasaki
University had a dense vegetation of trees, shrubs, and herbaceous plants, and was surrounded by human dwellings. The size of Maejima Island was about $400 \mathrm{~m}$ by $200 \mathrm{~m}$ ( $8.3 \mathrm{ha})$ and the distance from the opposite seashore to the island was about $500 \mathrm{~m}$. Dense vegetation of evergreen trees, shrubs as well as under-growing grasses covered nearly the whole island. The available host animals on the campus of Nagasaki University, School of Medicine were men, birds, cats, rats and dogs, whereas on Maejima Island rats were rare and probably only birds were available as a blood source of mosquitoes because of the small size of the island and no human dwellings on the island.

\section{Mosquito collection}

Flying mosquitoes were collected at a pair of collection sites with different height from the ground by a suction trap with $1 \mathrm{~kg}$ of dry ice operated by batteries in August and September 2001, and in June and July 2002. The design of the suction trap was similar to the CDC-light trap (Service, 1993); made from a $14 \mathrm{~cm}$ length of $8.5 \mathrm{~cm}$ internal diameter acrylic tubing, and a $3.0-\mathrm{V}$ motor with a threebladed fan made of plastic was operated from four 1.5-V dry batteries. The dry ice was wrapped with paper and kept in a Styrofoam-box. A piece ofdryicealways remained in thebox after $24 \mathrm{~h}$ of collection. Five and two trees growing at the forest fringe were selected on the campus of Nagasaki University, School of Medicine and on Maejima Island, respectively. A rope was hung on a branch of the tree, and two traps were hung at different positions by using the rope; one trap hung near the tree canopy and the other one

Table 1. Height of collection site (m) from the ground examined in this study.

\begin{tabular}{|c|c|c|c|c|c|c|c|}
\hline \multirow{2}{*}{ Position } & \multicolumn{5}{|c|}{ Campus of Nagasaki University } & \multicolumn{2}{|c|}{ Maejima Island } \\
\hline & Tree A & Tree B & Tree C & Tree D & Tree $\mathrm{E}^{*}$ & Tree 1 & Tree 2 \\
\hline High & 11.0 & 9.0 & 6.2 & 6.4 & 12.0 & 7.9 & 8.0 \\
\hline Low & 1.0 & 0.5 & 0.7 & 1.0 & 1.0 & 1.0 & 1.0 \\
\hline
\end{tabular}

*Middle position was used additionally at $6 \mathrm{~m}$ from the ground for Tree E. 
near the ground. The height of each collection site from the ground examined in this study is shown in Table 1. The trap was operated $24 \mathrm{hr}$ to collect both nocturnal and diurnal mosquito species.

\section{RESULTS}

The following 7 mosquito species were encountered on the campus of Nagasaki University, School of Medicine (Table 2); Ae. albopictus, Cx. pipiens pallens, Armigeres subalbatus, Cx. tritaeniorhynchus, Tripteroides bambusa, Cx. halifaxi, Orthopodomyia anopheloides. A total of 1,703 females of Ae. albopictus were collected from Trees $A-D$, and $3.9 \%$ of them were trapped near the tree canopy. The percentage of males of $A$ e. albopictus trapped near the tree canopy was only $1.2 \%(7 /$ 603 ) and significantly lower than that of females $\left(\chi^{2}=10.706, P=0.001\right)$. While in $C x$. pipiens pallens, the percentage of females trapped at near the tree canopy was $64.5 \%(394 / 611)$ and significantly higher $\left(\chi^{2}=1037.110, P<0.001\right)$ than that of $A e$. albopictus.

On Maejima Island the following 6 species were collected (Table 3 ) and Ae. albopictus was the most abundant; $A$ e albopict-

Table 2. Results of dry ice trap collection at a pair of collection sites on the campus of Nagasaki University, School of Medicine, in August 27-September 14, 2001 and June 4-14, 2002, Nagasaki, Japan.

\begin{tabular}{|c|c|c|c|c|c|c|c|c|c|c|c|c|}
\hline \multirow{3}{*}{ Species } & \multicolumn{12}{|c|}{ Position } \\
\hline & \multicolumn{6}{|c|}{ Low } & \multicolumn{5}{|c|}{ High } & \multirow{2}{*}{$\begin{array}{c}\% \\
\text { High } \\
1 \text { position }\end{array}$} \\
\hline & & $\begin{array}{l}\text { Tree A } \\
(1 \mathrm{~m})\end{array}$ & $\begin{array}{l}\text { Tree B } \\
(0.5 \mathrm{~m})\end{array}$ & $\begin{array}{c}\text { Tree C } \\
(0.7 \mathrm{~m})\end{array}$ & $\begin{array}{c}\text { Tree D } \\
(1 \mathrm{~m})\end{array}$ & Total & $\begin{array}{c}\text { Tree A } \\
(11 \mathrm{~m})\end{array}$ & $\begin{array}{c}\text { Tree B } \\
(9 \mathrm{~m})\end{array}$ & $\begin{array}{l}\text { Tree C } \\
(6.2 \mathrm{~m})\end{array}$ & $\begin{array}{l}\text { Tree D } \\
(6.24 \mathrm{~m})\end{array}$ & Total & \\
\hline \multirow[t]{2}{*}{ Aedes albopictus } & 우 & 304 & 193 & 704 & 436 & 1,637 & 14 & 3 & 27 & 22 & 66 & 3.9 \\
\hline & $\sigma^{\pi}$ & 78 & 85 & 254 & 179 & 596 & 4 & 1 & 1 & 1 & 7 & 1.2 \\
\hline Armigeres subalbatus & 우 & 1 & 1 & 4 & 11 & 17 & 0 & 0 & 1 & 3 & 4 & 19.0 \\
\hline \multirow{2}{*}{ Culex pipiens pallens } & 우 & 4 & 31 & 78 & 104 & 217 & 8 & 74 & 182 & 130 & 394 & 64.5 \\
\hline & $\sigma^{\pi}$ & 0 & 7 & 0 & 2 & 9 & 0 & 0 & 0 & 0 & 0 & 0.0 \\
\hline Cx. tritaeniorhynchus & 우 & 1 & 2 & 2 & 6 & 11 & 1 & 0 & 2 & 1 & 4 & 26.7 \\
\hline Cx. halifaxi & 우 & 0 & 0 & 0 & 1 & 1 & 0 & 0 & 1 & 1 & 2 & 66.7 \\
\hline Orthopodomyia anopheloides & 우 & 0 & 0 & 0 & 0 & 0 & 0 & 0 & 2 & 0 & 2 & 100.0 \\
\hline \multirow[t]{2}{*}{ Tripteroides bambusa } & 우 & 0 & 0 & 0 & 1 & 1 & 0 & 0 & 0 & 0 & 0 & 0.0 \\
\hline & $\sigma^{7}$ & 0 & 1 & 0 & 6 & 7 & 0 & 0 & 0 & 0 & 0 & 0.0 \\
\hline Number of days examined & & 9 & 10 & 20 & 20 & & 9 & 10 & 20 & 20 & & \\
\hline
\end{tabular}

Table 3. Results of dry ice trap collection at a pair of collection sites on a desert island, Maejima, in September 3-7, 2001, Nagasaki, Japan.

\begin{tabular}{|c|c|c|c|c|c|c|c|c|}
\hline \multirow{3}{*}{ Species } & \multicolumn{7}{|c|}{ Position } & \multirow{3}{*}{$\begin{array}{c}\% \\
\text { High } \\
\text { position }\end{array}$} \\
\hline & \multicolumn{4}{|c|}{ Low } & \multicolumn{3}{|c|}{ High } & \\
\hline & & $\begin{array}{c}\text { Tree } 1 \\
(1 \mathrm{~m})\end{array}$ & $\begin{array}{c}\text { Tree } 2 \\
(1 \mathrm{~m})\end{array}$ & Total & $\begin{array}{c}\text { Tree } 1 \\
(7.9 \mathrm{~m})\end{array}$ & $\begin{array}{c}\text { Tree } 2 \\
(8 \mathrm{~m})\end{array}$ & Total & \\
\hline \multirow{2}{*}{ Ae. albopictus } & 우 & 25 & 60 & 85 & 2 & 4 & 6 & 6.6 \\
\hline & $\sigma^{\pi}$ & 0 & 2 & 2 & 0 & & 0 & 0 \\
\hline Ochlerotatus nipponicus & 우 & 1 & 1 & 2 & 0 & 2 & 2 & 50 \\
\hline Ar. subalbatus & 우 & 11 & 1 & 12 & 2 & 0 & 2 & 14.3 \\
\hline Cx. pipiens pallens & 우 & 0 & 0 & 0 & 1 & 0 & 1 & 100 \\
\hline Cx. tritaeniorhynchus & 우 & 10 & 0 & 10 & 2 & 1 & 3 & 23.1 \\
\hline Tr. bambusa & 우 & 3 & 0 & 3 & 0 & 0 & 0 & 0 \\
\hline Number of days examined & & 5 & 5 & & 5 & 5 & & \\
\hline
\end{tabular}


Table 4. Results of dry ice trap collection at 3 different positions for Tree $\mathrm{E}$ on the campus of Nagasaki University, School of Medicine, in July 3-5, 2002, Nagasaki, Japan.

\begin{tabular}{|c|c|c|c|c|c|}
\hline \multirow{2}{*}{ Species } & & \multicolumn{3}{|c|}{ Position } & \multirow[b]{2}{*}{ Total } \\
\hline & & Low (1 m) & Middle $(6 \mathrm{~m})$ & High (12 m) & \\
\hline \multirow[t]{2}{*}{ Ae. albopictus } & 우 & $181(98.4)$ & $2(1.1)$ & $1(0.5)$ & $184(100)$ \\
\hline & $\sigma^{\pi}$ & $148(99.3)$ & $1(0.7)$ & $0(0)$ & $149(100)$ \\
\hline Ar. subalbatus & 우 & $1(50.0)$ & $1(50.0)$ & $0(0)$ & $2(100)$ \\
\hline Cx. pipiens pallens & 우 & $4(4.7)$ & $72(83.7)$ & $10(11.6)$ & $86(100)$ \\
\hline Cx. tritaeniorhynchus & 우 & $5(62.5)$ & $2(25.0)$ & $1(12.5)$ & $8(100)$ \\
\hline Cx. halifaxi & 우 & $0(0)$ & $1(100)$ & $0(0)$ & $1(100)$ \\
\hline Cx. bitaeniorhynchus & 우 & $0(0)$ & $1(100)$ & $0(0)$ & $1(100)$ \\
\hline
\end{tabular}

The value in parentheses shows the percentage.

us, Ochlerotatus nipponicus, Ar. subalbatus, $C x$. pipiens pallens, Cx. tritaeniorhynchus, and $T r$. bambusa. The percentage of female Ae. albopictus trapped near the tree canopy was $6.6 \%(6 / 91)$. The difference in the percentage of $A e$. albopictus trapped near the tree canopy was not significant between the campus of Nagasaki University and Maejima Island $\left(\chi^{2}=1.656, P=\right.$ 0.198). The small number of $C x$. pipiens pallens on Maejima Island was ascribed mainly to the scarcity of breeding sites on the island. There were no breeding sites on the island also for Cx. tritaeniorhynchus, however, 13 females were collected during the study. These females might immigrate from the mainland, since this species has good dispersal ability and can disperse $>10 \mathrm{~km}$ (Wada et al., 1969).

On Tree E which was taller than Trees A-D on the campus of Nagasaki University, 3 dry ice traps were hung at 3 different positions; low ( $1 \mathrm{~m})$, middle $(6 \mathrm{~m})$ and high $(12 \mathrm{~m})$. A total of 6 species were collected and a sufficient number of Ae. albopictus and $C x$. pipiens pallens were collected for statistical analysis (Table 4). The composition of female mosquitoes trapped at the 3 different positions was significantly different between $A$ e. albopictus and $C x$. pipiens pallens $\left(\chi^{2}=238.818, P<0.001\right)$. More than $80 \%$ of $C x$. pipiens pallens was trapped at the middle position and only $4.7 \%$ was trapped near the ground, while in $A e$. albopictus a large part of females (98.4\%) was trapped near the ground.

\section{DisCUSSION}

A clear difference in vertical distribution of flying mosquitoes was found between Ae. albopictus and Cx. pipiens pallens in this study which was similar to the contrast between Ae. cantans and Cx. pipiens observed in England (Service, 1971). Culex pipiens pallens are basically avian feeders (Tanaka et al., 1979) and more than $60 \%$ of females were collected near the tree canopy, while more than $90 \%$ of Ae. albopictus, which prefers to feed upon mammals (Hawley, 1988), was collected near the ground in our study. Although the proportion of Ae. albopictus trapped near the tree canopy was low, birds might be one of the host animals of Ae. albopictus in Nagasaki, Japan since this species showed high feeding activity even in night time (Higa et al., 2000) and high possibility to encounter birds during the night is expected for host-seeking females. Because $A e$ albopictus is highly susceptible to West Nile Virus (Turell et al., 2001; Sardelis et al., 2002), it could be an important bridge vector of West Nile virus from wild birds to human.

There was no human dwelling on Maejima Island. Mammals, such as rats and rabbits, were rare and birds were the most abundant host animals of $A$ e. albopictus on the island. Therefore, the proportion of females trapped near the tree canopy was expected to be higher on Maejima Island 
than that on the campus of Nagasaki University where cats, dogs, rats and human as well as birds were available for biting females. However, the percentage of $A e$. albopictus females trapped near the tree canopy was not significantly different between the two study areas in this study. This result suggested that host-seeking behavior of $A$ e. albopictus was not affected by the availability of host animals.

The vertical distribution of $C x$. pipiens pallens observed on Tree $\mathrm{E}$ as well as Trees A-D suggested the importance of a tree canopy for biting females in determining the place of feeding. The canopy of Tree E had a double layer, and the middle trap was hung at near the lower layer. Although the trap at the highest position was hung near the top layer, the layer was thin and often exposed to strong wind. These differences in environmental conditions of the tree canopy between the high and middle positions on Tree E might be the main reason for the highest proportion of collected females $(>80 \%)$ at the middle position.

Our results suggested that not only the distribution of host animals but also other factors, such as flight ability, host-seeking behavior and microclimate conditions around the tree canopy, might determine the vertical distribution of flying mosquitoes.

\section{REFERENCES}

Bernard, K. A., Maffei, J. G., Jones, S. A., Kauffman, E. B., Ebel, G. D., Dupuis II, A. P., Ngo, K. A., Nicholas, D. C., Young, D. M., Shi, P., Kulasekera, V. L., Edison, M., White, D. J. and Stone, W. B., NY State West Nile Virus Surveillance Team and Kramer, L. D. 2000. West Nile virus infection in birds and mosquitoes, New York State, 2000. Emerg. Infect. Dis., 7: 679-685.

Clements, A. N. 1999. The Biology of Mosquitoes, Vol. 2. Sensory reception and behaviour. 740 pp. CABI Publishing, Oxon, UK.

Corbet, P. S. 1961a. Entomological studies from a high tower in Mpanga Forest, Uganda. VI. Nocturnal flight activity of Culicidae and Tabanidae as indicated by light-traps. Trans. R. Entomol. Soc. London, 113: 336-345.

Corbet, P. S. 1961b. Entomological studies from a high tower in Mpanga Forest, Uganda. VIII. The age-composition of biting mosquito populations according to time and level. Trans. R. Entomol. Soc. London, 113: 336-345.

Gillies, M. T. 1988. Anopheline Mosquitoes: vector behaviour and bionomics. In: Malaria: Principles and Practices of Malariology, Vol. 1 (ed. Wernsdorfer W. H. and Sir McGregor, I.), pp. 453-485. Churchill Livingston, London.

Gillies, M. T. and Wilkes, T. J. 1976. The vertical distribution of some West African mosquitoes (Diptera: Culicidae) over open farmland in a freshwater area of the Gambia. Bull. Entomol. Res., 66 : 5-15.

Haddow, A. J., Corbet, P. S. and Gillett, J. D. 1961. Entomological studies from a high tower in Mpanga Forest, Uganda. I. Introduction. Trans. R. Entomol. Soc. London, 113: 249-256.

Hawley, W. A. 1988. The biology of Aedes albopictus. J. Am. Mosq. Control Assoc., 4 (suppl. 1): 1-40.

Higa, Y., Tsuda, Y., Tuno, N. and Takagi, M. 2000. Tempo-spatial variation in feeding activity and density of Aedes albopictus (Diptera: Culicidae) at peridomestic habitat in Nagasaki, Japan. Med. Entomol. Zool., 51: 205-209.

Iriarte, W. L. Z., Tsuda, Y., Wada, Y. and Takagi, M. 1991. Distribution of mosquitoes on a hill of Nagasaki city, with emphasis to the distance from human dwellings. Trop. Med., 33: 55-60.

Kulasekera, V. L., Kramer, L., Nasci, R. S., Mostashari, F., Cherry, B., Trock, S.C., Glaser, C. and Miller, J. R. 2000. West Nile virus infection in mosquitoes, birds, horses, and humans, Staten Island, New York, 2000. Emerg. Infect. Dis., 7: 722-725.

Sakakibara, S. 1980. Studies on environmental interaction between urban areas and shrine forest. 6 . Observations of egg laying activities by Aedes albopictus Skuse at various heights in the forest of Tsu-Hachimangu shrine. Rep. Environ. Sci., Mie Univ., 5: 43-52 (In Japanese with English summary).

Sardelis, M. R., Turell, M. J., O'Guinn, M. L., Andre, R. G. and Roberts, D. R. 2002. Vector competence of three North American strains of Aedes albopictus for West Nile virus. J. Am. Mosq. Control Assoc., 18: 284-289.

Service, M. W. 1971. Flight periodicities and vertical 
distribution of Aedes cantans (Mg.), Ae. geniculatus (Ol.), Anopheles plumbeus Steph. and Culex pipiens L. (Dipt., Culicidae) in southern England. Bull. Entomol. Res., 60: 639-651.

Service, M. W. 1993. Mosquito Ecology, Field Sampling Methods. $2^{\text {nd }}$ ed. 988 pp. Elsevier Applied Science, London.

Snow, W. F. 1975. The vertical distribution of flying mosquitoes (Diptera: Culicidae) in West African savanna. Bull. Entomol. Res., 65: 269-277.

Snow, W. F. 1979. The vertical distribution of flying mosquitoes (Diptera: Culicidae) near an area of irrigated rice-fields in the Gambia. Bull. Entomol. Res., 69: 561-571.

Snow, W. F. 1982, Further observations on the vertical distribution of flying mosquitoes (Diptera: Culicidae) in West African savanna. Bull. Entomol. Res., 72: 695-708.

Snow, W. F. and Wilkes, T. J. 1977. Age composition and vertical distribution of mosquito populations in the Gambia, West Africa. J. Med. Entomol., 13:
507-513

Tanaka, K., Mizusawa, K. and Saugstad, E. S. 1979. A revision of the adult and larval mosquitoes of Japan (including the Ryukyu archipelago and the Ogasawara Islands) and Korea (Diptera: Culicidae). Contrib. Am. Entomol. Inst. (Ann Arbor), 16: 1-987.

Turell, M. J., O'Guinn, M. L., Dohm, D. J., Jones, J. W. 2001. Vector competence of North American mosquitoes (Diptera: Culicidae) for West Nile virus. $J$. Med. Entomol., 38: 130-134.

Tsuda, Y., Takagi, M. and Wada, Y. 1994. Ecological study on mosquito communities in tree holes in Nagasaki, Japan with special reference to Aedes albopictus (Diptera: Culicidae). Jpn. J. Sanit. Zool., 45: 103-111.

Wada, Y., Kawai, S., Oda, T., Miyagi, I., Suenaga, O., Nishigaki, J., Omori, N., Takahashi, K., Matsuo, R., Itoh, T. and Takatsuki, Y. 1969. Dispersal experiments of Culex tritaeniorhynchus in Nagasaki area (Preliminary Report). Trop. Med., 11: 37-44. 